\title{
THE BARRIERS AGAINST EFFECTIVE UNIVERSITY INDUSTRY COLLABORATION: A STUDY IN TURKISH AVIATION INDUSTRY
}

\author{
DOI: 10.17261/Pressacademia.2019.1032 \\ JMML- V.6-ISS.1-2019(4)-p.35-43
}

\section{Ozge Peksatici', Hande Sinem Ergun ${ }^{2}$}

1 Özyeğin University, Faculty of Aviation and Aeronautical Sciences, Istanbul, Turkey. ozge.peksatici@ozyegin.edu.tr, ORCID: 0000-0001-9277-6268

${ }^{2}$ Marmara University, Faculty of Business Administration, Istanbul, Turkey. sergun@marmara.edu.tr, ORCID: 0000-0003-3885-8902

Date Received: February 2, 2018

Date Accepted: March 12, 2019

To cite this document

Peksatici, O., Ergun, H. S. (2019). The barriers against effective university industry collaboration: A study in Turkish aviation industry. Journal of Management, Marketing and Logistics (JMML), V.6(1), p.35-43.

Permemant link to this document: $\mathrm{http} / / /$ doi.org/10.17261/Pressacademia.2019.1032

Copyright: Published by PressAcademia and limited licenced re-use rights only.

\begin{abstract}
Purpose - The aim of this study is to explore the current situation of collaboration and knowledge transfer between aviation industry and higher education institutions offering aviation management programs in Turkey and to identify the perceived barriers against effective collaborations and knowledge transfer from industry point of view.

Methodology - Semi-structured interviews were used to meet the research objectives. The data was analyzed with the help of MaxQda qualitative data analysis program.

Findings - The findings reveal that there is poor collaboration and knowledge transfer between aviation management departments of universities and aviation industry in Turkey. The main barriers against effective collaboration and knowledge transfer from aviation industry actors' perspectives are the lack of research orientation of the academy, lack of industry experience and practical knowledge of the academicians, and lack of commercial mindset of the academicians. In addition, academy and industry having different motivations for collaborations, academy being slow in adapting to changes and poor collaboration culture of the industry are other important barriers identified by the industry actors.

Conclusion - It is expected that the implications brought by this study would help aviation industry and aviation academy partners in developing sustainable collaborations.
\end{abstract}

Keywords: University-industry collaborations, knowledge transfer, Turkish aviation industry, higher education, qualitative study JEL Codes: O39, L93, 123

\section{INTRODUCTION}

Today, universities are no longer institutions that only educate students and prepare them for their working lives. Besides producing professionals and skilled labors, universities now have the task of creating new knowledge with research, transferring knowledge to society by producing high impact innovation and driving the development of local economies through collaborations with industry (Draghici, Babana, Gogana, \& Ivascua, 2015). An effective collaboration between university and industry offers fruitful opportunities and new insights for both sides (Ankrah \& Al-Tabbaa, 2015).

Turkey has been one of the fastest growing aviation markets in the world (DGCA, 2017). Given the growing demand for skilled personnel at all levels in the aviation industry, number of aviation management undergraduate programs offered by universities has increased substantially. There are 24 universities offering 4- year aviation management programs and 32 universities offering 2-years programs (OSYM, 2018). Considering the role of the universities in the knowledge-based economy, it is expected that aviation higher education programs have close collaboration with the industry to contribute to its development. 
Despite extensive research on university industry collaborations (UIC), there has been no research on the collaborations between aviation industry and higher education institutions offering aviation management programs. It is therefore very important to analyze the current situation of UICs and knowledge transfer between aviation between industry and higher education institutions offering aviation management programs in Turkey and identify the barriers against effective collaborations and knowledge transfer. Based on the findings, it is expected to give suggestions to both sides for achieving effective and sustainable collaborations.

\section{LITERATURE REVIEW}

University-industry collaboration (UIC) refers to the interaction between higher education institutions and industry aiming to encourage knowledge and technology transfer (Bekkers \& Freitas, 2008; Siegel, Waldman, \& Link, 2003). Knowledge transfer is the process of transferring tacit and explicit knowledge to individuals and organizations to leverage intellectual capital and to ensure organizational learning (Argyris and Schön, 1996; Ulrich, 1998). The focus of Technology Transfer (TT), on the other hand, is to transform university driven research into commercialized solutions needed by the business world (Teece, 1987).

UICs can be classified into formal and informal engagements. Formal engagements include licensing of university patents, university spin-offs, employment of graduates, collaborative Research and Development (R\&D), co-publications and moving staff between universities and firms. Informal engagements include meetings, jointly attended lectures and conferences (Striukova \& Rayna, 2015).

Industry-university collaboration offers various benefits for both sides (Ankrah, Burgess, Grimshaw, \& Shaw, 2013). For the universities, collaborations would help academicians to explore new ways for improving the curriculum, to align theory and practice, and to adapt their teaching methods for offering better education to their students in parallel with the industry's needs (Santoro \& Gopalakrishnan, 2000). This would enable universities to better prepare students for the business world and make their transition into industry easier (Lee \& Win, 2004; Santoro \& Betts, 2002). In addition, through collaborations, students as well as the faculty members can learn about the real-life problems that industry is dealing with and have the opportunity to access the latest technology used by the industry (Santoro \& Chakrabarti, 2002). Moreover, UIC enables universities to commercialize academic research and to exploit intellectual property rights or licensing of patents (Logar, Ponzurick, Spears, \& France, 2001). Furthermore, by collaborating with the industry, academicians have the chance to be recognized within the scientific community through joint publications, conference presentations, and research grants (Harman \& Sherwell, 2002; Siegel, Waldman, Atwater, \& Lin, 2004).

UIC provides many advantages to the industry as well. UIC is regarded as an excellent way of stimulating business growth (Klofsten \& Jones-Evans, 1996). By collaborating with university, firms can gain competitive advantage and improve their financial performance by benefiting from academic research outputs (George, Zahra, \& Wood, 2002; Grant, 1996). In addition, universities can offer access to a variety of research expertise and infrastructure to the industry partners (Sherwood, Butts, \& Kacar, 2004). Academic research can improve the capacity of businesses to solve complex problems (Pavitt, 1988). Moreover, through effective collaboration with the university, industry partners can access highly skilled graduates, faculty facilities and laboratory equipment for research (Dutrénit, De Fuentes, \& Torres, 2010; Guimón, 2013). Furthermore, training collaborations with universities would offer extending opportunities for learning at work as well.

However, successful collaboration between industry and university is a challenging process. There can be various barriers that inhibit successful collaborations and knowledge transfer between universities and industry (Bruneel, D'Este \& Salter, 2010; Cricelli \& Grimaldi, 2010). These barriers differ from the perspectives of academy and industry actors. From the academics' perspective, the main factors that impede university-industry collaborations are the lack of understanding each other's expectations, different interests and needs, lack of government funding, difficulty in contacting individuals from the industry and bureaucratic structures of firms (Muscio \& Vallanti, 2014 as cited in Smirnova, 2015). On the other hand, from the firms' perspective insufficient collaborative infrastructure between industry and academy, excessive bureaucracy, lack of transparency in universities and firms' belief that their R\&D is adequate for innovation are the main factors hindering UICs (Joseph \& Abraham, 2009; Rasiah \& Govindaraju, 2009; Smirnova, 2015). Other commonly identified barriers by both sides are the lack of understanding and trust between the parties (Gopalakrishnan \& Santoro, 2004; Schiller \& Lee, 2015) low interest in collaboration (Schiller, 2006), lack of shared vision (Welsh, Glenna, and Lacy, 2008), intellectual property issues, different motivations (D'este \& Perkmann, 2011), and transaction costs (Bruneel et al., 2010). These identified barriers may vary in different industrial contexts (Bruneel et al., 2010) as firms that operate in different industrial sectors seem to attribute different levels of importance to interact with the universities (Pavitt, 1984; Levin, 1988; Salter \& Martin, 2001). 


\section{DATA AND METHODOLOGY}

The aim of this study is to explore the current situation of UICS and knowledge transfer between aviation industry and higher education institutions offering aviation management programs in Turkey and to identify the perceived barriers against effective collaborations and knowledge transfer from industry actors' point of view.

Semi-structured interviews were used to gather data to reveal the industry participants' perceptions, experiences and thoughts on the subject. The sample included 15 industry managers with more than 10 years of experience in aviation industry from airport operators, airlines, and ground handling companies. Purposive sampling was chosen as the sampling strategy as it helps the researcher to choose the right candidates for getting the most insightful results for the study (Cresswell, 2012). The data was analyzed with the help of MaxQda, a qualitative data analysis program. The tables throughout the study displays sample verbatim explanations of the participants and shows how many of the industry participants expressed the identified themes in their speech.

\section{FINDINGS AND DISCUSSIONS}

Based on the answers of the participants, it was discovered that there is poor collaboration between aviation management departments of universities and aviation industry in Turkey. Based on the statements of the participants, the only type of collaborations identified was:

- Industry managers attending seminars and giving speeches

- Industry helping universities for preparing course content

- Industry giving part-time courses and

- Industry hiring student interns (Please see Table 1 for participants' sample verbatim explanations).

No other type collaboration such as joint-research, collaborative Research and Development (R\&D), co-publications, consulting, training, etc. between both sides were identified (Please see Table 1 for participants' verbatim explanations).

It was also discovered that there is no effective knowledge transfer between aviation management departments of universities and aviation industry. The knowledge transfer in identified collaborations seems to be one way - only from industry to academia. The industry in most cases is the one providing the knowledge. As identified by the industry managers, in order to have successful collaborations, there should be a "win-win" situation for both sides. Therefore, they don't find the existing collaborations sustainable and valuable. (Please see Table 1 for participants' sample verbatim explanations).

Table 1: Poor Collaboration and Knowledge Transfer with Sample Excerpts

\begin{tabular}{|c|c|}
\hline Codes & Sample Excerpts \\
\hline $\begin{array}{l}\text { Poor collaboration defined } \\
\text { (Number of participants cited: 7) }\end{array}$ & $\begin{array}{l}\text { - "We are not collaborating with aviation departments of universities." } \\
\text { - "Industry manager 11) } \\
\text { "Unfortunately, we do not have much collaboration with the aviation } \\
\text { managen 12) } \\
\text { - "I think there isn't enough collaboration between aviation departments of } \\
\text { universities and the industry." (Industry manager 15) }\end{array}$ \\
\hline $\begin{array}{l}\text { Poor knowledge transfer defined } \\
\text { (Number of participants cited: } 5 \text { ) }\end{array}$ & $\begin{array}{l}\text { - "There is not effective knowledge transfer." (Industry manager 11) } \\
\text { - "Unfortunately, what I feel is there is not effective knowledge transfer." } \\
\text { (Industry manager 12) } \\
\text { - "There is only one-way knowledge transfer in these collaborations. The } \\
\text { industry does not get much in turn." (Industry manager 13) }\end{array}$ \\
\hline $\begin{array}{l}\text { Conference } \& \text { seminar } \\
\text { (Number of participants cited: } 9 \text { ) }\end{array}$ & $\begin{array}{l}\text { - "We do not have any collaboration with these departments besides giving } \\
\text { - "We attend seminars organized by aviation departments." (Industry } \\
\text { manager 5) } \\
\text { - "Some managers from our company are invited to conferences and } \\
\text { seminars and give some part of the courses." (Industry manager 11) }\end{array}$ \\
\hline
\end{tabular}




\begin{tabular}{|c|c|}
\hline $\begin{array}{l}\text { Hiring Interns } \\
\text { (Number of participants cited: 9) }\end{array}$ & $\begin{array}{l}\text { - "We hire interns from these programs." (Industry manager 2) } \\
\text { - "Our partnership does not go beyond hiring interns." (Industry manager } \\
\text { - } 10 \text { ) } \\
\text { "Our only collaboration with aviation departments of universities is hiring } \\
\text { interns." (Industry manager 12) }\end{array}$ \\
\hline $\begin{array}{l}\text { One-way knowledge transfer \& } \\
\text { benefit } \\
\text { (Number of participants cited: } 6 \text { ) }\end{array}$ & $\begin{array}{l}\text { - "It is not enough only to give us interns. Win-win gatherings, } \\
\text { collaborations should be organized." (Industry manager 2) } \\
\text { - "If you want to go beyond a 'one off' collaboration, there should be a win- } \\
\text { win for both sides. They just invite us for seminars, we give it and that's } \\
\text { all." (Industry manager 6) } \\
\text { - "Universities want support from us. They ask us to give seminars, courses } \\
\text { etc. but they do nothing in turn. There is only one-way knowledge transfer } \\
\text { in these collaborations. The industry does not get much in turn." (Industry } \\
\text { manager 13) }\end{array}$ \\
\hline
\end{tabular}

In order to understand the main barriers that inhibit successful collaboration between aviation management programs and aviation industry, related questions were asked to industry participants. It was revealed that an important barrier against effective collaboration between aviation industry and higher education institutions offering aviation management is that there is a gap between what these programs offer and what the industry values (Please see Table 2 for participants' sample verbatim explanations).

Table 2: The Gap Defined with Sample Excerpts

\begin{tabular}{|c|c|}
\hline Codes & Sample Excerpts \\
\hline $\begin{array}{l}\text { The Gap Defined } \\
\text { (Number of participants cited: } 9 \text { ) }\end{array}$ & $\begin{array}{l}\text { - "Knowledge levels of academy and industry is totally different." (Industry } \\
\text { - "Thanager 1) } \\
\text { (Industry manager 5) } \\
\text { - "Two sides (aviation academy and industry) they are two separate } \\
\text { worlds." (Industry manager 9) }\end{array}$ \\
\hline
\end{tabular}

It seems that an important reason that results in a gap between what these programs offer and what the industry managers require and a poor collaboration between both sides is the poor research orientation of academicians (Please see Table 3 for participants' sample verbatim explanations).

Table 3: Academy Teaching- Oriented with Sample Excerpts

\begin{tabular}{|c|c|}
\hline Codes & Sample Excerpts \\
\hline $\begin{array}{l}\text { Academy - teaching oriented \& } \\
\text { no research obligation } \\
\text { (Number of participants cited: } 6 \text { ) }\end{array}$ & $\begin{array}{l}\text { - "I swear I did not see even one publication on aviation in Turkey. Academy } \\
\text { is too busy in teaching. They never come to ask to do some knowledge } \\
\text { exchange." (Industry manager 2) } \\
\text { - "In the United States, the system forces academicians to do research. } \\
\text { Research is as important as teaching. But in Turkey, this is not the case." } \\
\text { (Industry manager 7) } \\
\text { "What I see in Turkey is, the publications and projects on aviation is very } \\
\text { poor in Turkey." (Industry manager 9) }\end{array}$ \\
\hline
\end{tabular}

Even if there are some academicians who conduct research in these programs, effective collaboration with the industry still cannot be achieved. According to the industry actors' claims, different motivations of academy seems to be an important barrier against collaborations. In most cases, when academicians engage in collaborations, the main motivation is to contribute to their academic career and walk forward in their career path, whereas the industry holds different motivations. Also, the industry actors state that because universities do not encourage academicians to do research and bring funding to the university with joint projects, academicians are not motivated to be closer with the industry and collaborate (Please see Table 4 for participants' sample verbatim explanations). 
Table 4: Motivation of Academy with Sample Excerpts

\begin{tabular}{|c|c|}
\hline Codes & Sample Excerpts \\
\hline $\begin{array}{l}\text { Motivation of academy } \\
\text { (Number of participants cited: } 5 \text { ) }\end{array}$ & $\begin{array}{l}\text { - "Academicians do research, but the main motivation is to do publications } \\
\text { and advance in their career, to become associate profs, or profs etc." } \\
\text { (Industry manager 5) } \\
\text { "In the US, or UK, academicians have to do applicable research and share } \\
\text { results with the industry. They manage it like a profit center. But in } \\
\text { Turkey, we are far behind that." (Industry manager 6) } \\
\text { "In the US, academicians have to get projects from the industry. If an } \\
\text { academician does not bring funding to the university with projects, they } \\
\text { will not keep him/her. This why, the concerns of academicians change and } \\
\text { they try to be closer to the industry and want to collaborate. But in Turkey } \\
\text { there is no such demand from academicians. (Industry manager } 7 \text { ) } \\
\text { "Academicians want to progress their academic career by focusing on } \\
\text { publications, not searching for any interaction with the industry" (Industry } \\
\text { manager } 8 \text { ) }\end{array}$ \\
\hline
\end{tabular}

In addition, the industry managers believe that academicians of aviation programs do not know the dynamics of the industry, and they do not understand the needs, problems and expectations of the industry. This has been identified as an important barrier against effective collaboration between both sides. The industry managers believe that the reason that academicians do not know the needs of the industry is that they do not have work experience and they stay away from the industry (Please see Table 5 for participants' sample verbatim explanations).

Table 5: Academy Away from the Industry with Sample Excerpts

\begin{tabular}{ll}
\hline Codes & Sample Excerpts \\
\hline - "Academy is not aware of the business world. They are not aware of what \\
is being done here. They are buried in their own fields. They say they do \\
the research, but they cannot bring anything solid" (Industry manager 3) \\
- "To make good projects, academicians should be in touch with us, learn \\
what are the pinpoints, where we have the most difficulties, where we are \\
running to, what are the new trends, which topics take most of our time, \\
where should we lead to... etc." (Industry manager 8) \\
- "Because when they develop a project by looking at theory only, this \\
doesn't help the industry, and doesn't create the reaction needed from \\
actual needs of the industry \\
(Number of participants cited: 7) \\
the industry. Academicians need to know the actual needs of the industry, \\
and work on subjects that the industry needs...Because without knowing \\
the business processes, it is not possible to develop solutions for the \\
industry. The solution should be applicable." (Industry manager 9) \\
- "Universities do not know what we want...Universities should understand \\
what I am doing." (Industry manager 10) \\
"These programs need to know what we really want. We should come \\
together and discuss this." (Industry manager 14) \\
- "There are no academicians with industry experience teaching in these \\
departments. They try to follow the new trends, but their industrial \\
knowledge is very poor." (Industry manager 1 )
\end{tabular}


- "The academician profile in Turkey has isolated itself from the industry. I don't understand why the academicians don't go to the industry and ask whether they can do R\&D for them, or if the industry needs any support from the academy." (Industry manager 5)

Academy away from the industr • "Academicians should be very close with industry and managers." (Number of participants cited:10 (Industry manager 6)

- "We don't know academicians, they don't present themselves, we don't know what they do, what they can do differently for us." (Industry manager 8)

- "These programs are staying away from the industry." (Industry manager 15)

Moreover, another barrier identified by the industry managers is that universities are coming behind the industry and they are too slow in adopting to changes and meeting the needs of the industry. They also highlight academic bureaucracy of the universities as an important barrier against collaborations (Please see Table 6 for participants' sample verbatim explanations).

Table 6: Academy Slow in Adapting with Sample Excerpts

\begin{tabular}{ll}
\hline Codes & Sample Excerpts \\
\hline - "In Turkey, we are facing too many bureaucracies on university side. So, \\
we prefer to get trainings from foreign academicians. Because if we want \\
to do it with a Turkish professor, he comes up with hundreds of \\
procedures: 'if the rector gives approval, if the university receives this \\
much money, if only on these dates, but first our dean has to approve...' \\
etc. We wouldn't work with them in this case. I want to pay and get what I \\
want quickly." (Industry manager 8) \\
(Number of participants cited:3) \\
"Academic bureaucracy is difficult that is faced in many universities." \\
(Industry manager 7) \\
- "In aviation, by giving education from a book published 2-years ago, you \\
are already far behind the industry realities. Industry is changing so fast. \\
Academicians should be following it and they should be the ones teaching \\
us the new things, not us." (Industry manager 4) \\
"If the book that we are using in class was published 5 years ago, the \\
data used inside belongs to 8-10 years ago. They are far behind the \\
industry." (Industry manager 7) \\
"Academy is coming behind the industry and the technology. We don't \\
believe they are following the new trends and technologies. They are too \\
industry \\
(Number of participants cited: 4) \\
slow in adapting to changes. We are talking about artificial intelligence, \\
block chain, etc. In order these topics to be taught at the universities, 4-5 \\
years must pass. It is easier to learn things from internet than from \\
universities." (Industry manager 3)
\end{tabular}

As a result, it seems that according to industry's point of view, because the academicians do not know the needs of the industry, because of lack of commercial mindset of those who conduct research, because of different motivations of the academicians for collaboration, and because of academy is so slow in adapting the industry's needs, the outcomes of the research conducted by the industry do not satisfy industry's needs (Please see Table 7 for participants' sample verbatim explanations). 
Table 7: Unrealistic \& Inapplicable Solutions with Sample Excerpts

\begin{tabular}{ll}
\hline Codes & Sample Excerpts \\
\hline & - "Academicians live inside a fish glass and do not cross-check with industry \\
to see whether the research they have done can be applied. It is \\
important that the research conducted serves the industry. "(Industry \\
manager 5)
\end{tabular}

Lastly, the industry actors believe that having no collaboration culture is an important barrier against effective UICs. They believe that the industry does not know how to work in collaboration (Please see Table 8 for participants' sample verbatim explanations).

Table 8: Lack of Collaboration Culture with Sample Excerpts

\begin{tabular}{ll}
\hline Codes & Sample Excerpts \\
\hline$-\quad$ "Industry is very closed to innovation. For example, there are some high \\
qualified publications, but the industry doesn't give attention and care. \\
This culture doesn't exist here. There is too much focus on operation. No \\
one cares about collaboration, change or how to do things better." \\
(Industry manager 8) \\
Lack of collaboration culture \\
(Number of participants cited: 6) \\
"The corporate firms are not used to working with academicians. Both \\
sides do not know how to work together. This is the main problem, I \\
think. We recently started working with technology transfer offices of \\
universities." (Industry manager 3) \\
"People in companies do not think too much about 'what can I get from a \\
collaboration'. They do not have that vision yet." (Industry manager 4)
\end{tabular}

\section{DISCUSSIONS \& CONCLUSION}

The aim of this study was to explore the current situation of UICS and knowledge transfer between aviation industry and higher education institutions offering aviation management programs in Turkey and to identify the barriers against effective collaborations and knowledge transfer from industry point of view.

It was discovered that there is poor collaboration and knowledge transfer between aviation management departments of universities and aviation industry in Turkey. The main reasons that result in barriers against effective collaboration and knowledge transfer between both sides from aviation industry actors' perspectives were:

- Academicians at aviation management programs are more teaching-oriented than research-oriented

- Academicians at aviation management programs do not have industry experience and practical knowledge

- Different motivations of academy for research

- Lack of commercial mindset of aviation departments when research conducted and

- Academy coming behind the industry

As a result of these factors, aviation management programs cannot meet aviation industry's needs and expectations and there is a gap between what these programs offer and what the industry managers require. In addition, the industry actors believe that lack of collaboration culture of industry is another most important barrier against effective collaboration and knowledge transfer between both sides.

Aviation management programs are industry-focused programs and therefore they should not only aim to raise labor for the industry but should also aim to create new knowledge with research, transfer knowledge to the industry by producing 
innovation and support the development of the industry through collaborations. In order to do so, the academic actors of these departments should understand the needs and expectations of the industry well and be closer to the aviation industry. The barriers that result in poor collaboration between both sides should be identified and tackled.

Since the industry complains that aviation academicians are staying away from the industry and that they do not know the realities of the industry, academicians teaching in these programs should spend some days with the industry to learn the industry's actual needs and expectations. The university should support the academicians in aviation management departments for being closer with the industry. The academicians would then be able to identify potential areas they can help the industry with. This would create a win-win situation for both sides and enable collaborations. The universities should also encourage academicians to do research and bring funds to the university with research. In this way, the concerns of academicians would change, and they'd like to be closer to the industry and to collaborate with them. It is also recommended universities to support academicians who are doing applicable research and bringing solutions to the industry's problems.

To the knowledge of the researcher, this study was the first attempt to focus on the UICs between aviation management programs and aviation industry in Turkey. It is expected that the practical implications brought by this study would help aviation industry and aviation academy partners in developing sustainable collaborations. For further research, a similar study should be conducted on the academy side and aviation management academicians' opinions about the barriers against effective collaboration and knowledge transfer should be identified. Moreover, the factors causing these barriers should be investigated and actions should be taken to tackle with them. Moreover, this study can be transferred into a quantitative survey format and conducted on a large scale of industry actors to statistically confirm its validity.

\section{REFERENCES}

Ankrah, S., Al-Tabbaa, O. (2015). Universities-industry collaboration: A systematic review. Scandinavian Journal of Management, 31, $387-408$

Ankrah, S. N., Burgess, T. F., Grimshaw, P., Shaw, N. E. (2013). Asking both university and industry actors about their engagement in knowledge transfer: What single-group studies of motives omit. Technovation, 33(2-3): 50-65

Argyris, C., Schön, D. A. (1996). Organizational learning II: Theory, method, and practice. MA: Addison Wesley Publishing Company.

Bekkers, R. N. A., Freitas, I. M. B. (2008). Analysing knowledge transfer channels between universities and industry: to what degree do sectors also matter? Research Policy, 37(10): 1837-1853.

Bruneel, J., D'Este, P., Salter, A. (2010). Investigating the factors that diminish the barriers to university-industry collaboration. Research Policy, 39(7): 858-68.

Cresswell, J. W., Plano Clark, V. L. (2011). Designing and conducting mixed method research. 2nd Sage; Thousand Oaks: CA.

Cricelli, L., Grimaldi, M. (2010). Knowledge-based inter-organizational collaborations. Journal of Knowledge Management, 14(3): 348-358.

D'este, P., Perkmann, M. (2011). Why do academics engage with industry? The entrepreneurial university and individual motivations. Journal of Technology Transfer, 36(3): 316-339 (2.

DGCA. (2017). Sivil havacilik genel müdürlüğü faaliyet rapor. Retrieved from http://web.shgm.gov.tr/documents/sivilhavacilik/files/pdf/kurumsal/faaliyet/2017.pdf

Draghici, A, Baban, C. F., Gogana, M. L., Ivascua, L. V. (2015). A knowledge management approach for the university-industry collaboration in open innovation. Procedia Economics and Finance, 23: 23-32

Dutrénit, G., De Fuentes, C., Torres, A. (2010). Channels of interaction between public research organisations and industry and their benefits: evidence from Mexico. Science and Public Policy, 37(7): 513-526.

George, G., Zahra, S. A., Wood, D. R. (2002). The effects of business-university alliances on innovative output and financial performance: A study of publicly traded biotechnology companies. Journal of Business Venturing, 17(6): 577-609.

Gopalakrishnan, S., Santoro, M. D. (2004). Distinguishing between knowledge transfer and technology transfer activities: The role of key organisation factors. IEEE Transaction of Engineering Management, 51(1):57-69

Grant, R. M. (1996). Prospering in dynamically competitive environments: Organizational capability as knowledge integration. Organization Science, 7(4): 375-387.

Guimón, J. (2013). Promoting university-industry collaboration in developing countries. World Bank. Retrieved from http://innovationpolicyplatform.org/sites/default/files/rdf_imported_documents/PromotingUniversitylndustryCollaborationlnDevelopingC ountries.pdf 
Harman, G., Sherwell, V. (2002). Risks in university-industry research links and the implications for university management. Journal of Higher Education Policy and Management, 24(1): 37-51.

Joseph, K. J., Abraham, V. (2009). University-industry interactions and innovation in India: patterns, determinants, and effects in select industries. Seoul Journal of Economics, 22(4): 467-498

Klofsten, M., Jones-Evans, D., Lindell, P. (1996). Growth factors in technology-based spin-offs: A Swedish study. Piccola Impresa/Small Business Journal, 10(3): 1-25.

Lee, J., Win, H. N. (2004). Technology transfer between university research centers and industry in Singapore. Technovation, 24(5), 433442.

Levin, R. C. (1988). Appropriability, R\&D spending and technological performance. The American Economic Review, 78(2): 424-428.

Logar, C. M., Ponzurick, T. G., Spears, J. R., France, K. R. (2001). Commercializing intellectual property: A university-industry alliance for new product development. Journal of Product and Brand Management, 10(4): 206-217.

Muscio, A., Vallanti, G. (2014). Perceived obstacles to university-industry collaboration: Results from a qualitative survey of Italian academic departments. Industry and Innovation, 21(5): 410-429

OSYM. (2018). Merkezi yerlestirme ile ogrenci alan yuksekogretim lisans programları. Retrieved from https://dokuman.osym.gov.tr/pdfdokuman/2018/YKS/YER/Tablo4MinMax 31082018.pdf

Pavitt, K. (1984). Sectoral patterns of technical change: towards a taxonomy and a theory. Research Policy, 13(6): 343-373.

Pavitt, K. L. R. (1988). International patterns of technological accumulation. In Hood, N \& Vahlne J. E. (Eds), Strategies in global competition. London: Croom Helm.

Rasiah, R., Govindaraju, V. G. R. (2009). University - industry R\&D collaboration in the automotive, biotechnology and electronics firms in Malaysia. Seoul Journal of Economics, 22(4): 529-550.

Salter, A. J., B. R. Martin (2001). The economic benefits of publicly funded research: a critical review. Research Policy, 30(3): 509-539.

Santoro, M. D., Betts, S. C. (2002). Making industry-university partnerships work. Research Technology Management, 45(3): 42- 46.

Santoro, M. D., Chakrabarti, A. K. (2002). Firm size and technology centrality in industry-university interactions. Research Policy, 31(7): 1163-1180.

Santoro, M. D., Gopalakrishnan, S. (2000). The institutionalization of knowledge transfer activities within industry-university collaborative ventures. Journal of Engineering and Technology Management, 17(3-4): 299-319.

Schiller, D. (2006). Nascent innovation systems in developing countries: University responses to regional needs in Thailand. Industry and Innovation, 13(4): 481-504.

Schiller, D., Lee, K. (2015). Are university-industry linkages meaningful for catch-up? A comparative analysis of five Asian countries. In Albuquerque, E., Wilson, S., Kruss,G. Lee, K. (Eds.) Developing National Systems of Innovation: University-Industry Interactions in the Global South (pp. 55-92). Cheltenham: Elgar.

Sherwood, A. L., Butts, S. B., Kacar, S. L. (2004). Partnering for knowledge: A learning framework for university-industry collaboration. Midwest Academy of Management, 2004 Annual Meeting, 1-17

Siegel, D. S., Waldman, D., Link, A. (2003). Assessing the impact of organizational practices on the relative productivity of university technology transfer offices: an exploratory study. Research Policy, 32(1): 27-48.

Siegel, D. S., Waldman, D. A., Atwater, L. E., Link, A. N. (2004). Toward a model of the effective transfer of scientific knowledge from academicians to practitioners: Qualitative evidence from the commercialization of university technologies. Journal of Engineering and Technology Management, 21(1-2): 115-142.

Smirnova, Y. V. (2015). University-industry knowledge transfer in an emerging economy: Evidence from Kazakhstan. Science and Public Policy, 43(5): 702-712.

Striukova, L., Rayna, T. (2015). University-industry knowledge exchange: An exploratory study of open innovation in UK universities. European Journal of Innovation Management, 18(4): 471-492.

Teece, D. (1987). Profiting from technological innovation: Implications for integration, collaboration, licensing and public policy. In: Teece, D. (Ed.), The Competitive Challenge. Ballinger, Cambridge: MA.

Ulrich, D. (1998). Intellectual Capital = Competence X Commitment. Sloan Management Review, 39: 15-26.

Welsh, R., Glenna, L., Lacy, W. (2008). Close enough but not too far: Assessing the effects of university-industry research relationships and the rise of academic capitalism. Research Policy, 37(10): 1854-1864. 